Review

\title{
A framework to implement Stakeholder participation in environmental projects
}

\author{
Vincent Luyet ${ }^{\mathrm{a}}$, Rodolphe Schlaepfer ${ }^{\mathrm{b}, *}$, Marc B. Parlange ${ }^{\mathrm{a}}$, Alexandre Buttler ${ }^{\mathrm{b}}$

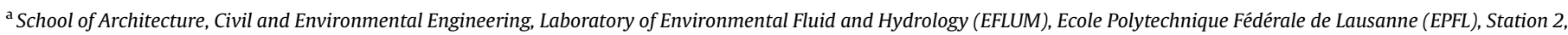 \\ 1015 Lausanne, Switzerland \\ ${ }^{\mathrm{b}}$ Ecole Polytechnique Fédérale de Lausanne (EPFL), Laboratory of Ecological Systems (ECOS), Station 2, 1015 Lausanne, Switzerland
}

\section{A R T I C L E I N F O}

\section{Article history:}

Received 26 April 2010

Received in revised form 22 May 2012

Accepted 17 June 2012

Available online

\section{Keywords:}

Stakeholder participation

Environmental project

Framework

Switzerland

\begin{abstract}
A B S T R A C T
Participation has emerged as an appropriate approach for enhancing natural resources management. However, despite long experimentation with participation, there are still possibilities for improvement in designing a process of stakeholder involvement by addressing stakeholder heterogeneity and the complexity of decision-making processes.

This paper provides a state-of-the-art overview of methods. It proposes a comprehensive framework to implement stakeholder participation in environmental projects, from stakeholder identification to evaluation. For each process within this framework, techniques are reviewed and practical tools proposed. The aim of this paper is to establish methods to determine who should participate, when and how. The application of this framework to one river restoration case study in Switzerland will illustrate its strengths and weaknesses.
\end{abstract}

(c) 2012 Elsevier Ltd. All rights reserved.

\section{Introduction}

In recent decades, there has been an increased interest in participation for environmental decision making (Reed, 2008; Hansen and Mäenpää, 2007; Abelson et al., 2007). Public participation around the world has been part of a wide range of environmental applications including integrated watershed management (Sabatier et al., 2005; ISPWDK, 2005; Kenney et al., 2000), agricultural development (Wilson, 2004; Chambers, 1994), ecosystem management (Knight et al., 2006), environmental governance (Rist et al., 2007), forest management (Buttoud and Yunusova, 2002; Carter and Gronow, 2005) and planning (Buchy and Hoverman, 2000; Buchecker et al., 2003). This is also reflected in a range of international agreements including the Earth Summit, the European Landscape Convention, the Aarhus Convention and the European Water Framework Directive.

Despite the general acceptance of participation, it is not always clear what distinguishes public involvement from stakeholder participation. There are many different definitions of participation (e.g. IAP2, 2009; Luyet, 2005; OECD, 2001; Steelman and Ascher, 1997 ) because participation is used in many contexts and understood in various ways (Reed, 2008; Mostert et al., 2007; OECD, 2001; Buchy and Hoverman, 2000; Davidson, 1998). Definitions depend on decision-making processes and who should participate.

\footnotetext{
* Corresponding author. Tel.: +4121693 57 71; fax: +41216933913.

E-mail address: rodolphe.schlaepfer@epfl.ch (R. Schlaepfer).
}

In this paper, participation is defined, following the World Bank (1996) as "a process through which stakeholders influence and share control over development initiatives and the decision and resources which affect them". For us, the purpose of stakeholder participation is to enhance the quality of the project, which could be defined in different ways depending on the project context (Rowe and Frewer, 2000). In our view, project quality mainly includes social learning and adequate technical solutions. This is possible through the support and cooperation between the involved parties and the resulting input of knowledge.

Distinctions are often made between the public and the stakeholders. In the literature however, these terms are not used consistently and may confuse rather than clarify understanding. The public is often considered as a collection of individuals generally unstructured and unorganized (Luyet, 2005; Kessler, 2004). On the other hand, stakeholder can be defined as "any group of people organised, who share a common interest or stake in a particular issue or system" (Grimble and Wellard, 1997). In this paper, we consider the public as one specific stakeholder and therefore we use the term stakeholder participation rather than public participation.

The literature provides a wide range of case studies illustrating the advantages and risks of participation. Table 1 shows that there are as many risks as advantages. It is important, before implementing a specific participatory system, to know them in order to optimize the participation process. In addition, a number of clear principles for successful participation can be identified, including: 
Table 1

Advantages and risks of public participation.

\section{Advantages of participation}

- Better trust in decisions (Richards et al., 2004; OECD, 2001; Beirle, 2000)

- Improving project design using local knowledge (Irvin and Stansbury, 2004; Habron, 2003; Beierle and Cayford, 2002),

- Better understanding projects and issues (Duram and Brown, 1999)

- Integration of various interests and opinions (Griffin, 1999; Creighton, 1986)

- Optimizing implementation of plans and projects (Irvin and Stansbury, 2004; Konisky and Beierle, 2001),

- Public acceptance of the decisions (Reed, 2008; Junker et al., 2007),

- Fostering and developing social learning (Blackstock et al., 2007; Junker et al., 2007; Pahl-Wostl, 2002; Beierle and Cayford, 2002)

Risks of participation

- Expensive process (Mostert, 2003; Lawrence and Deangen, 2001; Vroom, 2000)

- Time consuming process (Luyet, 2005; Smith Korfmacher, 2001; Vroom, 2000)

- Potential stakeholder frustration (Reed, 2008; HarmoniCOP, 2005; Irvin and Stansbury, 2004; Germain et al., 2001)

- Identification of new conflicts (Kangas and Store, 2003; Germain et al., 2001; Cooke and Kothari, 2001)

- Involvement of stakeholders who are not representative (Reed, 2008; Junker et al., 2007; Smith Korfmacher, 2001)

- Empowerment of an already important stakeholder (Buttoud and Yunusova, 2002)

- A fair, equal, and transparent process that promotes equity, learning, trust and respect among stakeholders and the administration (Reed, 2008; Webler et al., 2001; Moote et al., 1997),

- The integration of local and scientific knowledge (Reed, 2008; Tippett et al., 2007),

- The establishment of rules in advance (Sabatier et al., 2005; Renn et al., 1995),

- An early involvement of stakeholders (Leach et al., 2002; Leach and Pelkey, 2001),

- The integration of all stakeholders (Smith Korfmacher, 2001; Duram and Brown, 1999),

- The presence of experienced moderators (Reed, 2008; Leach et al., 2002; Griffin, 1999), and

- Adequate resources, including time (Leach and Pelkey, 2001; Keeney et al., 2000)

Even if these principles are applied, critical situations can happen. For example, it must be stressed that simply copying the best examples of public participation will not guarantee success in other case studies. Cultural, political and historical contexts should also be taken into account (Stenseke, 2009; Abelson et al., 2007 HarmoniCOP, 2005; Sabatier et al., 2005; Irvin and Stansbury, 2004; Vroom, 2003; Sobel et al., 2001). Another example is the practice to focus on only specific, limited aspects of the process (Reed, 2008; Abelson et al., 2007; Buchy and Hoverman, 2000). Participation is often reduced to the dissemination of information and the holding of workshops (Rowe et al., 2004; Chess and Purcell, 1999). These approaches generally do not take into account either the heterogeneity of stakeholders (Reed, 2008), or the complexity of the decision making process (French and Geldermann, 2005; Chess and Purcell, 1999; Abelson et al., 2007; Mostert, 2003; Luyet, 2005).

The aim of this paper is to provide a state-of-the-art review of literature in the environmental field regarding stakeholder participation. Based on this overview of good and bad practices, a comprehensive framework for designing adequate stakeholder participation is proposed and discussed for one case study located in Switzerland.

\section{Methods and framework description}

This section reviews the literature, highlighting discussions that concern environmental projects and their participation techniques. Our proposed framework, presented in Fig. 1, is the result of this analysis (Luyet, 2005). It is structured as a system with inputs (e.g. environmental policy), outputs (e.g. decisions) and processes. To implement such a system, stakeholders must be identified, characterized and organized, in order to give them a specific degree of participation, thereby accounting for their heterogeneity. Participatory techniques must then be chosen according to the specified degree of participation. The idea is that stakeholders can be involved to different degrees, using parallel and varying participatory techniques. Finally, when the entire process has been completed, an evaluation must be conducted. In the following sections, each step of this framework will be described.

\subsection{Stakeholder identification}

Several papers present stakeholder identification techniques. Creighton (1986) developed a set of criteria such as proximity, economy, use and social values to identify stakeholders. Selman (2004) distinguishes between stakeholders who have an economic interest and those motivated by principles or values. A technique proposed by Mitchell et al. (1997) consists of identifying stakeholders by taking into account their legitimacy, urgency and proximity. The snowball technique (King et al., 1998; Stanghellini and Collentine, 2008) starts with brainstorming. The list of stakeholders obtained through this brainstorming is then submitted to one of the identified stakeholders, soliciting his/her opinion and allowing him/her to add further stakeholders. Special attention has to be given in the snowball technique due to the risk of reproducing network homogeneity. This can be avoided by using multiple entry points, which generate a more balanced set. Mason and Mitroff (1981) propose a technique using a set of questions, for which the answers generate a list of stakeholders (Luyet, 2005; Banville et al., 1998).

The choice of a specific identification technique will mainly depend on the project context, the project phase and the available resources. As mentioned in the introduction, the integration of all stakeholders is one principle for a successful participation. Failing to identify some stakeholders may introduce bias in the subsequent stages of the process. Another consequence of unidentified stakeholders is the possibility for them to appear later and have negative impacts on the project (Luyet, 2005). Performing the identification process with several heterogeneous persons can minimize these risks. On the other hand, involving all possible stakeholders may increase the complexity and the cost of the participation process. The challenge is to find the optimum balance between these risks.

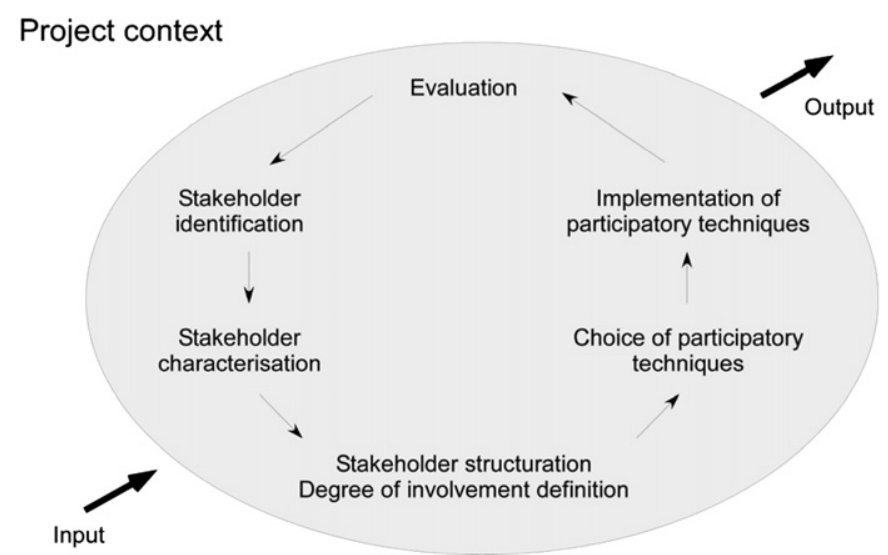

Fig. 1. Proposed framework for stakeholder participation. 
Table 2

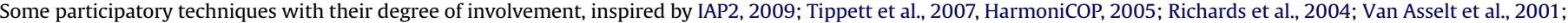
OECD, 2001 and Rowe and Frewer, 2000.

\begin{tabular}{|c|c|c|c|c|c|}
\hline Participation technique & Information & Consultation & Collaboration & Co-decision & Empowerment \\
\hline Newsletter & $\mathrm{X}$ & & & & \\
\hline Reports & $\mathrm{X}$ & & & & \\
\hline Presentations, public hearings & $\mathrm{X}$ & $\mathrm{X}$ & $\mathrm{X}$ & & \\
\hline Internet webpage & $\mathrm{X}$ & $\mathrm{X}$ & & & \\
\hline Interviews, questionnaires and surveys & $\mathrm{X}$ & $\mathrm{X}$ & $\mathrm{X}$ & & \\
\hline Field visit and interactions & $\mathrm{X}$ & $\mathrm{X}$ & $\mathrm{X}$ & & \\
\hline Workshop & & $\mathrm{X}$ & $\mathrm{X}$ & $\mathrm{X}$ & $\mathrm{X}$ \\
\hline Participatory mapping & & & $\mathrm{X}$ & $\mathrm{X}$ & $\mathrm{X}$ \\
\hline Focus group & & & $\mathrm{X}$ & $\mathrm{X}$ & $\mathrm{X}$ \\
\hline Citizen jury & & $\mathrm{X}$ & $\mathrm{X}$ & $\mathrm{X}$ & $\mathrm{X}$ \\
\hline Geospatial/ decision support system & $\mathrm{X}$ & $\mathrm{X}$ & $\mathrm{X}$ & $\mathrm{X}$ & \\
\hline Cognitive map & $\mathrm{X}$ & $\mathrm{X}$ & $\mathrm{X}$ & & \\
\hline Role playing & & & $\mathrm{X}$ & $\mathrm{X}$ & $\mathrm{X}$ \\
\hline Multicriteria analysis & & & $\mathrm{X}$ & $\mathrm{X}$ & \\
\hline Scenario analysis & & $\mathrm{X}$ & $\mathrm{X}$ & $\mathrm{X}$ & $\mathrm{X}$ \\
\hline Consensus conference & & $\mathrm{X}$ & $\mathrm{X}$ & $\mathrm{X}$ & $\mathrm{X}$ \\
\hline
\end{tabular}

\subsection{Stakeholder characterization}

In the case of small projects or when the number of identified stakeholders is limited, the characterization process can be optional. Stakeholders should be characterized in order to understand the power relations between them and their specific interest in the project. A variety of criteria have been proposed in the literature. They include:

- Attitudes towards a project (Banville et al., 1998),

- Potential conflicts and coalitions between stakeholders and objectives (Fottler et al., 1989; Elliot and Schlaepfer, 2001),

- Interest in the project (FAO, 2000; Varvasovszky and Brugha, 2000),

- Access to resources (Luyet, 2005; Crozier and Friedberg, 1977),

- Political influence over the project (Laumann and Knocke, 1987),

- Degree of implication (Luyet, 2005),

- Power, stakeholder urgency, proximity and legitimacy (Mitchell et al., 1997; Stenseke, 2009; Habermas, 1984), and

- Scale of influence (Rist et al., 2007).

Van Asselt et al. (2001) also drew stakeholder maps through which links, connections and relationship can be visualized.

There is generally no systematic approach to both the choice and the use of the mentioned criteria. They depend on the project context and objectives and should be transparent. Special attention has to be paid to the persons who characterize the stakeholders. Their judgment and analysis may be subjective. In order to minimize possible bias in stakeholder structuring and fixing their degree of involvement, several persons such as representative people, stakeholders themselves or experts should be asked (using a questionnaire or interview) to rank all stakeholders on a specific scale for each criterion.

\subsection{Stakeholder structuring and degree of involvement}

The principle of this procedure is to structure the identified stakeholders into homogeneous groups and to give to each group a specific degree of involvement. Arstein (1969), who wrote the first main contribution related to this topic, set out a ladder for citizen participation based on 8 steps. He structured the degrees of participation into three main groups: Nonparticipation (manipulation and therapy), Tokenism (informing, consultation, placation) and Citizen Power (partnership, delegated power and citizen control). Based on adaptations and revisions of Arnstein's ladder (Lawrence, 2006; HarmoniCOP, 2005; Vroom, 2003; Davidson, 1998; Weidermann and Femers, 1993),we use in our framework the five following degrees of participation:

- Information: explanation of the project to the stakeholders.

- Consultation: presentation of the project to stakeholders, collection of their suggestions, and then decision making with or without taking into account stakeholders input.

- Collaboration: presentation of the project to stakeholders, collection of their suggestions, and then decision making, taking into account stakeholders input.

- Co-decision: cooperation with stakeholders towards an agreement for solution and implementation,

- Empowerment: delegation of decision-making over project development and implementation to the stakeholders.

Bailey and Grossardt (2007, 2010) analyzed the difference between the perceived and desired positions on the Arnstein Ladder and called this difference the Arnstein Gap.

The question becomes how to implement these degrees of involvement for each identified stakeholder. Often, based on their own feeling and experience, project leaders define the degree of involvement for each stakeholder. This is not a standardized process and can be extremely subjective (Daniels et al., 1996; Daniels and Walker, 2001). However, Vroom's model (Vroom, 2003) proposes a systematic method to determine a specific level of involvement for each stakeholder. In Vroom's model, seven questions are asked sequentially. The answers allow the project management to attribute the appropriate degree of involvement. One limitation to Vroom's method could be, in case of low trust, that stakeholders do not believe the agency-collated data on desired involvement levels. This may happen if documented, quantitative stakeholder desires for their degree of participation are formulated. The best way to minimize this risk is to involve several people in the process of attributing the degree of involvement. Attributing levels of involvement to stakeholders is still an expert driven paradigm. Large-scale data from citizens would make such estimation more reliable. However, this process is time consuming. This is why we propose to include, beside the project leader, several people, for example: one or two stakeholders, experts and other people who are familiar with the context of the area.

The degree of involvement is a critical point in stakeholder participation because it influences all the processes, in particular, 
the choice of participative technique (Table 2). Attributing an inappropriate degree of involvement to a stakeholder can give too much or not enough power to a stakeholder, or it can lead to choosing an inadequate participation technique.

\subsection{Choice of participatory techniques}

In order to support a practical process of stakeholder participation, targeted participatory techniques must be determined. Obviously, they can only be chosen once the objectives and the degree of involvement of stakeholders have been defined (Reed, 2008). A plethora of techniques have been identified in the literature (HarmoniCOP, 2005; Van Asselt et al., 2001; IAP2, 2009). Currently, there is no standardised method to choose the most relevant participatory technique (Luyet, 2005; Van Asselt et al., 2001). The choice depends on many factors, including:

- Degree of involvement,

- Type of stakeholders (prior knowledge and experience, time available, interest, etc),

- Local cultural and social norms,

- Past events (history of development, etc),

- Intended timing of the use of the techniques within the project, and

- Knowledge and experience of the project manager/facilitator (Reed, 2008; Luyet, 2005; Mostert, 2003; Creighton, 1986).

Inspired by IAP2 (2009); Tippett et al. (2007); HarmoniCOP (2005); Richards et al. (2004); Van Asselt et al. (2001); OECD (2001) and Rowe and Frewer (2000), we have selected several participatory techniques (Table 2), which are linked to specific degrees of involvement. Attributing an inadequate participation technique can be considered the main risk leading to an unsuccessful participation process. One way to avoid this risk is to apply two or more different participation techniques to a stakeholder group.

\subsection{Implementation of participatory techniques}

Implementation starts once stakeholders are identified, characterized and structured, participation level attributed and participation techniques decided. Adherence to the principles in Section 1 , such as the early involvement of the stakeholders and the establishment of clear rules, is essential for a successful participation process. This implies that the project management clearly understands each step of the proposed participatory process, especially the participatory techniques. In order to motivate the stakeholders to remain active in the process until the end, an adequate information and publicity about the techniques is useful. An inappropriate implementation can lead to stakeholder's mistrust and frustration, and as consequence, a failure of the process.

\subsection{Evaluation of stakeholder participation}

The evaluation of a participation process is important in providing information to improve future similar applications, enhancing the understanding of its impacts on stakeholders and documenting experiences and outcomes. The evaluation of public participation processes has been examined in various papers during the last decade (Blackstock et al., 2007; Rowe et al., 2004; Schulz et al., 2003; Brinkerhoff, 2002; Rowe and Frewer, 2000). Generally, appropriate evaluation criteria can be divided into three groups:
- Those related to the process (e.g. organisation, communication (Brinkerhoff, 2002), conflict resolution (Asthana et al., 2002), early involvement, transparency, equity, influence (Grant and Curtis, 2004), stakeholder representativeness, integration of all interests and definition of rules (Rowe and Frewer, 2000; Beirle and Konisky, 2001; Rowe et al., 2004);

- Those related to the outcomes (e.g. accountability (Asthana et al., 2002), capacity building (Grant and Curtis, 2004), emergent knowledge (Asthana et al., 2002), impacts (Richards et al., 2004) and social learning (Mostert et al., 2007)

- And those linked to the political, social, cultural, historical and environmental context (Asthana et al., 2002).

Qualitative and quantitative techniques are used to evaluate participation. Techniques such as interviews or analyses of reports and minutes increase the probability of an in-depth understanding of the process (Blackstock et al., 2007). The Arnstein Gap, as used by Bailey and Grossardt (2010), is an interesting tool for understanding how far the stakeholders' desires about their involvement are fulfilled.

There is no standardized approach related to participation evaluation. The project management should choose its criteria depending not only on the goals of the project, but also on the focus, purpose and timing of the evaluation. A good evaluation has to be planned at an early stage, well organized, and has to integrate the three types of criteria mentioned above.

\section{Case study: the Third Rhone Correction Project (R3)}

The Third Rhone Correction Project (R3) has been chosen because of its economical and political importance, the large number of stakeholders involved, their heterogeneity and the river restoration context. The Swiss political system is a direct democracy, and traditionally, consensus building plays an important role at several levels. Consultation between different administration services is routine in Switzerland, but participation with nonadministrative stakeholders is rare for the Swiss administration. Participation is an obligation fixed in different federal and cantonal laws. For example, the federal law for land use planning requires public involvement. Also the laws give the right to make opposition to everyone touched by the project. This political and legal constellation explains why, for the R3 project, a participation process has been elaborated and implemented. In addition, two other constraints had to be considered: the deadline and the different phases of the R3 project.

The R3 project is the most important current river restoration project in Switzerland. It involves $160 \mathrm{~km}$ of river and a significant part of its valley. Its cost will be on the order of $€ 1.0$ billion over a period of 30 years. The $\mathrm{R} 3$ project has three main objectives (Canton du Valais, 2000, 2005):

- To ensure the flood protection of the Rhone plain;

- To enhance the river's environmental functions and;

- To enhance the river's socio-economic functions.

The land use changes associated with the project (e.g. conversion of agricultural land for the project purposes) are particularly controversial issues. The Rhone River and its catchment (about $4200 \mathrm{~km}^{2}$ ) have been the centre of a participative planning process for the entire R3 project design. The framework proposed in this paper has been applied to this project (Luyet, 2005). Besides many other stakeholders, three levels of authorities are involved: federal, cantonal and communal. All three must be integrated in the participation process. 
As a first step, using the technique developed by Mason and Mitroff (1981), about 50 different stakeholders (including the public) have been identified by four people (project manager, administration expert, regional expert and one stakeholder involved in the project). This technique was chosen for its simplicity. Potential stakeholders, who have not yet been established, have been identified, such as riverbank associations. Some citizens will probably only realize the real consequences of the project when they see the planned project outcomes published on a map. For example, during the design phase of the R3 project, the authorities actively promoted the creation of a new regional commission representing and integrating all interests related to the Valais plain (economical, ecological, political, cultural, and agricultural). Consequently, the $\mathrm{R} 3$ project had an opportunity to access the citizens affected by the project and therefore enhance its design, implementation, monitoring and evaluation.

In the second step, four people (project manager, administration expert, regional expert and one stakeholder involved in the R3 project) characterized the identified stakeholders using four criteria from the list in Section 2.2: involvement, resources, political influence and attitude toward $\mathrm{R} 3$ project. We consider these criteria as the most relevant at this early stage of the project.

For the third step of the framework (stakeholder structuring and degree of involvement), these same four experts answered the seven questions of the Vroom model for each stakeholder. The answers were studied with a cluster analysis allowing the identification of four degrees of involvement: information (14 stakeholders), consultation ( 7 stakeholders), collaboration (13 stakeholders) and co-decision (15 stakeholders).

For the choice of participatory technique (Section 2.4), the degree of involvement, the project phase and the Swiss context were considered. The selection of these techniques was based on their potential to identify stakeholder objectives and feedbacks and on the integration of stakeholders' opinions in the project design.

Specific techniques of participation have then been implemented (Section 2.5). Since 2003, information (newsletter production, public hearings), consultation (interviews and questionnaires), collaboration (focus group discussions, cognitive maps, multi-criteria analysis, scenario analysis, consensus conferences) and co-decision (advisory boards and workshops) were undertaken at different scales. For example workshops and focus groups have been set up for co-decision-making.

The last step of the proposed framework was a first qualitative evaluation by Luyet (2005). The interviews of project managers and every stakeholder (49 interviews), show what each stakeholder learned and how they understood the issues related to the project. During these interviews 13 criteria have been used: design of the process, integration of every interest, transparency, equity, definition of the rules, early involvement, facilitation, stakeholder representativeness, stakeholder competency, trust, social learning and impact of participation of the process and results. Stakeholders appreciated being involved in the early steps of the project. On the other hand, there were also criticisms of the participatory process with regard to costs, the time consuming nature of processes, the lack of clear answers, and unresolved conflicts, similar to the limitations identified by Bailey and Grossardt (2010). We are aware that this stakeholder evaluation does not correspond neither to the framework proposed by Rowe and Frewer (2000) nor to a quantitative approach. We preferred a qualitative evaluation because of the early stage of the project and its specific context. Three weaknesses can be mentioned. First, the stakeholders are not always representing the interests of the organization, which delegates them. Second, the evaluation was not based on quantitative information. Third, too few stakeholders are proactive in the process. Nevertheless, the application of the proposed participation framework has allowed the R3 project to involve stakeholders in a comprehensive way. It was successful from both the stakeholders' and project leader points of view because it has improved the design of technical solutions, developed social learning and understood the stakeholders' opinions. Therefore the R3 project management decided to generalize the use of this framework for the entire R3 program. It is interesting to notice that three years after the implementation of the participation process, stakeholders who were not identified at the beginning, made several oppositions against the project. This shows that one of the goals, an agreement about technical solutions of the project, is not realized.

\section{Discussion}

The proposed framework defines a specific degree of involvement for each stakeholder and was applied in a Swiss watershed management project. Strengths and weaknesses of the framework were identified during the evaluation process. The framework gives practical tools to practitioners. It is important to ensure that weaker stakeholders are not marginalized or discriminated against. Also, stakeholders who are potentially concerned by the project should be identified and integrated into the process. For example, in the R3 project, regional commissions and riverbank associations were created after the beginning of the project and identified as stakeholders. The early involvement of the stakeholders in the project was appreciated. Another advantage is that the project can identify all the relevant stakeholders and take into account their characteristics and heterogeneity in the decision making process. An accurate planning of participation should include clear information about the different steps of this process (phase, timing, duration...). This is essential to help stakeholders understand the project. On the other hand, costs and time requirements can be considered as weaknesses of the framework.

A critical issue is the selection of the degree of participation. It is not easy to accomplish this work in the eyes of external evaluators. A level of participation is never legitimate unless it is based on data from a wide cross-section of involved stakeholders.

The use of the framework can also include potential risks. For example, project leaders can fear they will lose their autonomy or project control (Bailey and Grossardt, 2010). Also, powerful stakeholders could be considered by others as sharing the project leader's opinion and this could create a schism and some mistrust between stakeholders. The evaluation of the participation process of the R3 case study shows that some stakeholders were happy with their degree of involvement, but others would have desired a higher degree of participation. This is a qualitative illustration of the Arnstein's gap (Bailey and Grossardt, 2010). One risk is to ignore a documented and quantitative stakeholder desire for their degree of participation.

The proposed framework structures the entire implementation of participation into processes using practical techniques, which can be adapted to various types of projects in landscape management, forestry, conservation, transport infrastructure and other disciplines. For each type of project it is necessary to account for the specific political, social and legal context, which gives project constraints and explains methodological choices. For example in Switzerland, opposition to projects is legally possible. As a consequence, participation is highly recommended and should end with a general agreement avoiding opposition.

Additionally, the framework can be adapted to the development of new information and communication technology (ICT), such as the e-ladder (Smyth, 2001) or the advanced geovisual analytical methods (Bailey et al., 2007). Where such technology can be used, the traditional public participation ladder has to be changed to integrate e-participation. The bottom rungs of Smyth's ladder 
represent the online delivery of services and facilitate a more interactive participation. Within the next few decades, ITC technology is likely to be more widely available, and project leaders will be required to use it to optimize public participation. Nevertheless, work such as Nyerges and Agguirre (2011) and Nyerges et al. (2006), dealing with online deliberation, give advice and limits regarding the design of ICT tools within the participation process. They also provide evidence that the role of technology in improving the quality of participation can be questionable.

In the overall participation debate, this paper addresses the questions of "who should participate?" and "how should they participate?". To answer the question "when?", the notion of project phases needs to be introduced (Stanghellini and Collentine, 2008; Hansen and Mäenpää, 2007). Phasing requires that our framework or another methodology must be applied at every step of the project: analysis and identifying objectives, designing technical solutions, decision-making, implementation, and assessment. Even the design step, which mainly entails input by engineers, can include options for stakeholder feedback.

\section{Conclusion}

Participation is still in development, from the conceptual as well as from the technical point of view. It is a complex system, with multiple purposes, interactions, meanings, degrees of involvement, methods, and solutions that are specific to each context and project. The result of this state-of-the-art overview of methods is the proposed framework for stakeholder participation. Its main strengths are its adaptability to different contexts, its holistic nature, its ability to integrate social and technical sciences, and its combination of these with practical participatory tools. Experiences and lessons from the case study in Switzerland show the importance of:

- The identification not only of the current stakeholders, but also the potential ones

- The specific attribution of degree of involvement taking into account the heterogeneity of the stakeholders

- The adequacy of the stakeholders input for the design of technical solutions.

On the other hand, the evaluation identifies some challenges in participation implementation. One of them is the need to invest enough time and thought in the planning phase, in order to minimize the risks mentioned in the paper.

\section{Acknowledgments}

The authors thank the anonymous reviewers for their valuable comments.

\section{References}

Abelson, J., Forset, P.G., Eyles, J., Casebeer, A., Martin, E., Mackean, G., 2007. Examining the role of context in the implementation of a deliberative public participation experiment: results from a Canadian comparative study. Social Science \& Medicine 64, 2115-2128.

Arstein, S.R., 1969. A ladder of citizen participation. Journal of American Institute of Planners 35, 216-224.

Asthana, S., Richardson, S., Halliday, J., 2002. Partnership working in public policy provision: a framework for evaluation. Social Policy and Administration 36, 780-795.

Bailey, K., Grossardt, T., Pride-Wells, M., 2007. Community design of a light rail transit-oriented development using casewise visual evaluation (CAVE). SocioEconomic Planning Sciences 41, 235-254.

Bailey, K., Grossardt, T., 2010. Towards structured public involvement: justice, geography and collaborative geospatial/geovisual decision support systems. Annals of the Association of American Geographers 100 (1), 57-86.
Banville, C., Landry, M., Martel, J.M., Boulaire, C., 1998. A stakeholder approach to MCDA. Systems Research 15, 15-32.

Beierle, T. C., 2000. Public participation in environmental decisions: an evaluation framework using social goals. Discuss. Pap 99-06, Resour. of the Future, Washington. D. C.

Beierle, T., Cayford, C., 2002. Democracy in Practice: Public Participation in Environmental Decision, report 158 pp. Resources of the Future, Washington. D. C.

Beierle, T.C., Konisky, D.M., 2001. What are we gaining from stakeholders involvement? Observations from environmental planning in the Great Lakes. Environmental Planning C Government Policy 19, 515-527.

Blackstock, K.L., Kelly, G.J., Horsey, B.I., 2007. Developing and applying a framework to evaluate participatory research for sustainability. Ecological Economics 60, 726-742.

Brinkerhoff, J.M., 2002. Assessing and improving partnership relationships and outcomes: a proposed framework. Evaluation and Program Planning 25 215-231.

Buchy, M., Hoverman, S., 2000. Understanding public participation in forest planning: a review. Forest Policy and Economics 1, 15-25.

Buchecker, M., Hunziker, M., Kienast, F., 2003. Participatory landscape development: overcoming social barriers to public involvement. Landscape and Urban Planning 64, 29-47.

Buttoud, G., Yunusova, I., 2002. A "mixed model" for the formulation of a multipurpose mountain forest policy ; theory vs. practice on the example of Kyrgyzstan. Forest Policy \& Economics 4 (2), 149-160.

Canton du Valais, 2000. Troisième correction du Rhône: rapport de synthèse. Service des routes et des cours d'eau, Sion. Valais. Suisse.

Canton du Valais, 2005. Plan sectoriel troisième correction du Rhône. Service des routes et des cours d'eau, Sion. Valais. Suisse.

Carter, J., Gronow, J., 2005. Recent experience in collaborative forest management: a review paper. CIFOR Occasional paper No.43, CIFOR, Bogar, Indonesia. 48 pp.

Chambers, R., 1994. The Origins and practice of participatory rural appraisal. World Development 22 (7), 953-969.

Chess, C., Purcell, K., 1999. Public participation and the environment. Do we know what works? Environmental Science and Technology 33 (16), 2685-2692.

Cooke, B., Kothari, U., 2001. Participation, the New Tyranny? Zed Books, London-New York.

Creighton, J.L., 1986. Managing Conflict in Public Involvement Settings: Training Manual for Bonneville Power Administration, Pablo Alto, California. Creighton and Creighton, Los Gatos, CA.

Crozier, M., Friedberg, E., 1977. L'acteur et le système: les contraintes de l'action collective. Editions du Seuil, Paris.

Daniels, S.E., Lawrence, R.L., Alig, R.J., 1996. Decision making and ecosystem based management: applying the Vroom Yetton model to public participation strategy. Environmental Impact Assessment Review 16, 13-30.

Daniels, S.E., Walker, G.B., 2001. Working through Environmental Conflicts: The Collaborative Learning Approach. Praeger Publishers, Westport, CT.

Davidson, S., 1998. Spinning the wheel of empowerment. Planning 3, 14-15.

Duram, L.A., Brown, K.G., 1999. Assessing public participation in US watershed planning initiatives. Society \& Natural Resources 12, 455-467.

Elliot, C., Schlaepfer, R., 2001. Understanding forest certification using the advocacy coalition framework. Forest Policy and Economics 2, 257-266.

FAO, 2000. Public Participation in Forestry in Europe and North America. International labour office, Geneva.

Fottler, M.D., Blair, J.D., Whitehead, C.J., Laus, M.D., Savage, G.T., 1989. Assessing key stakeholders: who matters to hospitals and why? Hospital and Health Services Administration 34, 525-546.

French, S., Geldermann, J., 2005. The varied contexts of environmental decision problems and their implications for decision support. Environmental Science and Policy 8, 378-391.

Germain, R.H., Floyd, D.W., Stehman, S.V., 2001. Public participation of the USDA forest service public participation process. Forest Policy and Economics 3, 113-124.

Grant, A., Curtis, A., 2004. Refining evaluation criteria for public participation using stakeholder perspectives of process and outcomes. Rural Society 14, 142-162.

Griffin, C.B., 1999. Watershed councils: an emerging form of public participation in natural resource management. Journal of the American Water Resources Association 35 (3).

Grimble, R., Wellard, K., 1997. Stakeholders methodologies in natural resources management: a review of principles, contexts, experiences and opportunities. Agricultural Systems 55 (2), 173-193.

Habermas, J., 1984. The Theory of Communicative Action: Reason and the Rationalization of Society. Beacon press, Boston.

Habron, G., 2003. Role of adaptive management for watershed councils. Environmental Management 31 (1), 29-41.

Hansen, S.H., Mäenpää, M., 2007. An overview of the challenges for public participation in river basin management and planning. Management of Environmental Quality 9 (1), 67-84.

HarmoniCOP project, 2005. www.harmonicopPuos.de.

IAP2, 2009. International Association for Public Participation (IAP2). http://www. iap2.org/associations/4748/files/06Dec_Toolbox.pdf.

Irvin, R.A., Stansbury, J., 2004. Citizen participation in decision making: is it worth the effort? Public Administration Review 64 (1), 55-65.

ISPWDK Indo-Swiss Participative Watershed Development Programme, 2005 Empowering the People: Experience with Village Development Societies in Promoting Local Governance. In: ISPWDK Programme Series, vol. 1. Intercooperation Delegation, Hyderabad, India. 
Junker, B., Buchecker, M., Müller-Böcker, U., 2007. Objectives of public participation: which actors should be involved in the decision making for river restorations. Water Resources Research 43 (10), W10438.

Kangas, J., Store, R., 2003. Internet and teledemocracy in participatory planning of natural resources management. Landscape and Urban Planning 62, 89-101.

Kenney, D.S., McAllister, S.T., Caile, W.H., Peckham, J.S., 2000. The New Watershed Source Book: a Directory and Review of Watershed Initiatives in the Western United States. Natural Resources Law Center, University of Colorado School of Law.

Kessler, B.L., 2004. Stakeholder Participation: A Synthesis of Current Literature. National Oceanic and Atmospheric Administration. www.mpa.gov.

King, C.S., Feltey, K.M., Sused, B.O., 1998. The question of participation: toward authentic public participation in public administration. Public Administration Review 58 (4), 317-326.

Knight, T.A., Cowling, R.M., Campbell, B., 2006. An operational model for implementation conservation action. Conservation Biology 20 (2), 408-419.

Konisky, D.M., Beierle, T.C., 2001. Innovation in public participation and environmental decision making: examples from the great lakes region. Society and Natural Resources 14 (9), 815-826.

Laumann, E.O., Knocke, D., 1987. The Organizational State, Social Choice for National Policy Domain. The university of Wisconsin Press, Wisconsin.

Lawrence, R.L., Deangen, D.A., 2001. Choosing public participation methods for natural resources: a context specific guide. Society and Natural Resources 14 (9), 857-872.

Lawrence, A., 2006. No personal motive? Volunteers, biodiversity, and the false dichotomies of participation. Ethics, Place and Environment 9, 279-298.

Leach, W.D., Pelkey, N.W., 2001. Making watershed partnerships work: a review of the empirical literature. Journal of Water Resources Planning and Management 127 (6), 378-385.

Leach, W.D., Pelkey, N.W., Sabatier, P.A. 2002. Stakeholders partnerships as collaborative policymaking: evaluation criteria applied to watershed management in California and Washington. Journal of Policy Analysis and Management 21 (4), 645-670.

Luyet, V., 2005. A Framework for the Participative Process in a Large Environmenta Project. Case study: the 3rd Rhone river correction. PhD thesis $\mathrm{Nr} 3342$, Swiss Federal Institute of Technology, Lausanne, Switzerland.

Mason, I., Mitroff, I.I., 1981. Challenging Strategic Planning Assumptions. John Wiley and sons, New York.

Mitchell, R.K., Agle, B.R., Wood, D.J., 1997. Toward a theory of stakeholder identification and salience: the principle of who and what really count. Academy of Management Review 22, 853-886.

Moote, M.A., Mcclaran, M.P., Chickering, D.K., 1997. Theory in practice: applying participatory democracy theory to public land planning. Environmental Management 21 (6), 877-889.

Mostert, E., Pahl-Wostl, C., Rees, Y., Searle, B., Tabara, D., Tippett, J., 2007. Social learning in European river-basin management: barriers and fostering mechanisms from 10 river basins. Ecology and Society 12 (1), 19. http://www. ecologyandsociety.org/vol12/iss1/art19/.

Mostert, E., 2003. The challenge of public participation. Water Policy 5, 179-197.

Nyerges, T., Agguirre, R.W., 2011. Public participation in analytic-deliberative decision-making: evaluating a large group online field experiment. Annals of the Association of American Geographers 101 (3), 561-586.

Nyerges, T., Jankowski, P., Tuthill, D., Ramsey, K., 2006. Collaborative water resource decision support: results of a field experiment. Annals of the Association of American Geographers [0004-5608] 96 (4), 699-725.

OECD, 2001. Citizen as Partners: Information, Consultation and Public Participation in Policy Making. OECD Publishing, Paris. http://www.eldis.org/static DOC11520.htm.

Pahl-Wostl, C., 2002. Towards sustainability in the water sector: the importance of human actors and processes of social learning. Aquatic Sciences 64, 394-411.
Reed, M.S., 2008. Stakeholder participation for environmental management: a literature review. Biological Conservation 141, 2417-2431.

Renn, O., Webler, T., Wiedermann, P., 1995. Fairness and competence in citizen participation: evaluating models for environmental discourse. Technology, Risk and Society 10.

Richards, C., Blackstock, K.L., Carter, C., 2004. Practical Approaches to Participation. In: SERP Policy Brief, vol. 1. Macaulay Institute, Aberdeen.

Rist, S., Chidambaranathan, M., Escobar, C., Wiesmann, U., Zimmermann, A., 2007. Moving from sustainable management to sustainable governance of natura resources: the role of social learning processes in rural India, Bolivia and Mali. Journal of Rural Studies 23 (1), 219-237.

Rowe, G., Frewer, L.J., 2000. Public participation methods: a framework for evaluation. Science Technology \& Human Values 25 (1), 3-29.

Rowe, G., Marsh, R., Frewer, L.J., 2004. Evaluation of a deliberative conference. Science Technology \& Human Values 29 (1), 88-121.

Sabatier, P.A., Vedlitz, A., Foch, W., Lubell, M., Matlock, M., 2005. Swimming Upstream: Collaborative Approaches to Watershed Management. In: American and Comparative Environmental Policy. MIT Press, 328 pp.

Schulz, A.J., Israel, B.A., Lantz, P., 2003. Instrument for evaluating dimension of group dynamics, within community based participatory research partnerships. Evaluation and Program Planning 26, 249-262.

Selman, P., 2004. Community participation in the planning and management of cultural landscape. Journal of Environmental Planning and Management 47, 365-392.

Smith Korfmacher, K., 2001. The politics of participation in watershed modelling. Environmental Management 27 (2), 161-176.

Smyth, E., 2001. Would the Internet widen public participation? MSc thesis. University of Leeds.

Sobel, J., Curtis, A., Lockie, S., 2001. The role of landcare group network in rural Australia: exploring the contribution of social capital. Journal of Rural Studies 17, 265-276.

Stanghellini, P.S., Collentine, D., 2008. Stakeholder discourse and water management - implementation of the participatory model $\mathrm{CATCH}$ in a Northern Italian alpine sub-catchment. Hydrol. Earth Syst. Sci 12, 317-331.

Steelman, T., Ascher, W., 1997. Public involvement methods in natural resource policy making: advantages, disadvantages and trade-offs. Policy Sciences 30, 71-90.

Stenseke, M., 2009. Local participation in cultural landscape maintenance: lessons from Sweden. Land Use Policy 26, 214-223.

Tippett, J., Handley, J.F., Ravetz, J., 2007. Meeting the challenges of sustainable development - a conceptual appraisal of a new methodology for participatory ecological planning. Progress in Planning 67, 9-98.

Van Asselt, M., Mellors, J., Rijkens-Klomp, N., Greeuw, S., Molendijk, K., Jelle Beers, P., Van Notten, P., 2001. Building Blocks for Participation in Integrated Assessment: A Review of Participatory Methods. ICIS, Maastricht.

Varvasovszky, Z., Brugha, R., 2000. A stakeholder analysis: how to do (or not to do). Health Policy and Planning 15 (3), 338-345.

Vroom, V., 2000. Leadership and the decision-making process. Organizational Dynamics 28 (4), 82-94.

Vroom, V., 2003. Educating managers for decision making and leadership. Management Decision 41 (10), 968-978.

Webler, T., Tuler, S., Krueger, R., 2001. What is a good public participation process? Five perspectives from the public. Environmental Management 27 (3), 435-450.

Weidermann, I., Femers, S., 1993. Public participation in waste management decision-making: analysis and management of conflicts. Journal of Hazardous Materials 33, 355-368.

Wilson, G.A., 2004. The Australian Landcare movement: towards 'post-productivist' rural governance? Journal of Rural Studies 20 (4), 461-484.

World Bank, 1996. The World Bank Participation Sourcebook. World Bank, Washington. 